\title{
EFFECT OF PACKAGING TYPE AND PERFORATION RATE ON STORABILITY AND QUALITY OF COMMON BEANS PODS: - A- PHYSICAL PROPERTIES
}

\author{
M.E.M. Ahmed(1), M.A.A. Mohamed(2), I.A. AlBallat(1) and K. A. I. Nomir(1) \\ (1) Tanta University, Faculty of Agriculture, Horticulture department, Tanta, Egypt. \\ (2) Fruit Handling Depart. HRI, MOA, Giza, Egypt.
}

Received: Dec. 20, 2020

Accepted: Dec. 30,2020

ABSTRACT: Common bean (Phaseolus vulgaris L.) is one of the most important members of leguminous crops grown in Egypt for either local consumption or exportation. For highly respiring produce such as mushrooms, peas and broccoli, traditional films like LDPE. However, the micro- perforated films are special films which are expensive and not available everywhere. This experiment was carried out at Fruit Handling Department laboratories, Horticultural Research Institute. Snap bean pods were obtained from a private farm at Giza, at suitable maturity stage of marketing. Uniform pods and free from blemishes were selected for storage experiment. Pods were packed in perforated or non-perforated polyethylene and polypropylene bags $(30 \mu \mathrm{m}$ thickness, $15 \times 25 \mathrm{~cm}$ size) and each bag had $250 \mathrm{~g}$ as one replicate. There were two perforation rates in addition normal perforation rate. All treatments were stored at $7^{\circ} \mathrm{C}$ and $90-95 \%$ relative humidity for $7,14,21$ days. Pods physical properties were recorded during storage.

A significant decrease in weight loss percentage was observed in all perforated and nonperforated treatments in comparison with normal perforation rate. The highest weight loss was associated with those stored in normal perforation rate compared with all the other treatments. While the lowest weight loss was associated with those stored in nonperforated treatment in comparison with all other treatments. On the other side, reducing perforation rate significantly reduced decay incidence of stored common beans compared with non-perforated and normal perforated bags. Common beans stored in the less perforation rate bags was associated with the less decay incidence during storage. However, there was no significant differences among these treatments. Also, these treatments significantly reduced deterioration rate in all other studied quality of common beans during storage. Moreover, it is clear that, although common bean pods packaged in polyethylene bags had quality parameter higher than those packaged in polypropylene bags during the two seasons, there was no significant differences among these treatments in these aspects. We can conclude that, reducing bag perforation rate well led to improve common beans storability and reduce its deterioration rate during storage.

Key words: Packaging type, perforation, storability, common bean quality.

\section{INTRODUCTION}

Common bean (Phaseolus vulgaris L.) is one of the most important members of leguminous crops grown in Egypt for either local consumption or exportation. It is rich in protein, dietary fibers, minerals ( $\mathrm{Ca}, \mathrm{P}, \mathrm{Fe}, \mathrm{K}, \mathrm{Mg}$ and $\mathrm{Mn}$ ) and vitamins ( $A, B_{1}, B_{2}$ and $\left.C\right)$ with high amino acids (Kerlous, 1997).

In Egypt common beans cultivated area is about 65150 feddans, (27363 ha) producing about 284299 tons in the year 2018, (Egypt, FAO Data, http://www.fao.org/faostat/en/\#data/QC). 
Furthermore, common beans crop in Egypt is considered the second vegetable export crop after potato crop. Common beans have great social and economic importance in Egypt because of its high commercial value, extensive production and nutritional value. On the other side, Egypt exported in the same year 14298 tons reached its value nearly 33442000

US\$

(http://www.fao.org/faostat/en/\#data/QC). Egypt hold the Eleventh rank between the important exporting countries of it in the same year. (http://www.fao.org/faostat/en/\#data/TP).

For highly respiring produce such as mushrooms, peas and broccoli, traditional films like LDPE, polyvinyl chloride (PVC), ethylene vinyl acetate (EVAC), oriented polypropylene (OPP) and cellulose acetate are not sufficiently permeable. The use of perforated films was recommended by Emond et al. (1991); Fishman et al. (1996). The highly permeable micro-perforated ones are most suitable for packaging highly respiring produce (Scetar et al., 2010). However, the micro- perforated films are special films which are expensive and not available everywhere (Rai et al., 2009). A combination of low temperature storage and closed polythene packaging has a very good preservation effect on the quality of vegetable like snap beans.

It has been reported that, weight loss percentage of green beans pods gradually and significantly increased with prolonging of storage period, Guo et al. (2008), Proulx et al. (2010), (Kinyuru et al. (2011), Ubhi et al. (2014), El-Sayed et al. (2015), Shehata et al. (2015), Soontornwat et al. (2015) and Shehata et al. (2018). The same results were mentioned by Gomaa et al. (2009) and Anurag et al. (2015) on green peas, Nasef et al. (2018) on snow peas, Gad EL-Rab (2013) and Shehata et al. (2019) on sweet pepper.

It has been reported that, French beans unpackaged had the higher weight loss during storage regardless of storage temperature in comparison with those packaged in LDPE $37.5 \mu \mathrm{m}$ packages, (Ubhi et al., 2014). They also added that, French beans packaged in bags having 4 perforations recorded the highest weight loss ( $0.65 \%$ on the 21 th day) followed by those packaged in bags having 2 perforations ( $0.56 \%$ on the 21th day) and then in non-perforated packages $(0.46 \%$ on the 21th day) however, it is still less than those un packed $(20.66 \%$ on the 21th day).

Shehata et al. (2015) and (2018) mentioned that snap bean pods packed in non-PPPb significantly reduced weight loss percentage as compared to those packed in micro-PPPb or normal perforated during storage and shelf life.

Anurag et al. (2015) in their study on green peas stored in modify atmosphere packaging (MAP) illustrated that the lowest weight loss percentage of green peas was observed in MAP samples having zero perforation followed by 3 perforated sample stored at the temperature range of 4 to $10^{\circ} \mathrm{C}$ and $90-$ $94 \mathrm{RH}$.

It has been demonstrated that snap bean pods decay, rot percentage and chilling injuries disorders of furrow and drip-irrigated pods during storage at $7 \pm 1^{\circ} \mathrm{C}$ and $85 \% \mathrm{RH}$. For 25 days increased gradually and significantly with prolonging of storage period, (Sandhya and Singh, 2004; Gomaa et al., 2009 on green peas and El-tahan, et al., 2016). Moreover, furrow-irrigated pods showed lower decay percentage and non-rotted pods than drip-irrigated ones at all investigated periods of storage. However, chilling injuries were observed on fruits as soggy tissues, brown spots and fruit shrinking. Furrow-irrigated pods showed less soggy tissue percentage than dripirrigated ones at all investigated periods during storage (El-tahan, et al., 2016). 
It has been illustrated that general appearance of green beans pods gradually and significantly decreased with prolonging of storage period and shelf life (Shehata et al., 2015, Shehata et al., 2018 and Nasef et al., 2018 on snow peas, Shehata et al., 2019 and Gad ELRab, 2013 on sweet pepper).,

Shehata et al. (2015) and (2018) demonstrated that green beans pods packed in non- perforated polypropylene bags showed the highest intensities of freshness, greenness, and snappiness in comparison with those packed in perforated polypropylene bags either micro or normal perforated during cold storage. They also cleared that green beans pods packed in micro- perforated polypropylene bags showed the lowest intensities of these attributes.

On contrast, Nasef et al. (2018) in their study on snow peas packaged in different type of perforated polypropylene packages in addition to non-perforated and control bag. They demonstrated that in micro-perforated films, especially with 12 micro-holes, showed the highest visual appearance. On contrast, the lowest score values were observed with non-perforated then smart packages overall cold storage plus retail sale periods.

It has been found that, firmness of green beans pods gradually and significantly decreased with prolonging of storage period, (Proulx, et al., 2010; Ubhi et al., 2014 in addition, Gad EL-Rab 2013 and Shehata et al., 2019 on sweet pepper).

Ubhi et al. (2014) illustrated that snap beans packed in LDPE $37.5 \mu \mathrm{m}$ film packages, package having four perforations recorded the highest firmness followed by package having two perforations and least firmness was recorded in non-perforated packages.

It has been illustrated that, lightness of green beans pods gradually and significantly increased with prolonging of storage, (Ubhi et al., 2014). The same results were illustrated by Anurag et al. (2015) on green peas. On the other side, Proulx, et al. (2010) cleared that lightness of green beans pods has no clear trend during storage. On contrast, Gad EL-Rab (2013) and Shehata et al. (2019) illustrated that, lightness of sweet pepper gradually and significantly decreased with the increasing of storage period.

Abd El-Mageed (2015) mentioned that common beans packed in polyethylene film had the highest intensities of freshness, greenness during storage as compared with those stored in polypropylene bags. There were no differences in weight loss between common beans stored in the different packaging materials.

Ubhi et al. (2014) illustrated that snap beans packed in LDPE $37.5 \mu \mathrm{m}$ film packages, package having 4 perforations recorded the least lightness followed by package having 2 perforations and the highest lightness was recorded in nonperforated packages.

Color of green beans pods gradually and significantly decreased with prolonging of storage period, (Ubhi et al., 2014 and Anurag et al. (2015) on green peas. On the other hand, Proulx, et al. (2010) illustrated that color of green beans pods represented as hue angle insignificantly decreased during storage.

On the other side, Gad EL-Rab (2013) and Shehata et al. (2019) illustrated that color of sweet pepper represented as $p$ values significantly decreased during storage.

Ubhi et al. (2014) illustrated that snap beans packed in LDPE $37.5 \mu \mathrm{m}$ film packages, package having 4 perforations recorded the highest greenness followed by package having two perforations and the least greenness was recorded in nonperforated packages.

Moreover, Anurag et al. (2015) demonstrated that green peas packed in unsealed packaging significantly had the highest $L$ value compared with those packed micro-perforated smart package. 
Therefore, the aim of this work was to study the effect of packaging of common bean pods in micro-perforated or nonperforated polypropylene and polypropylene bags on physical quality attributes and storability of common beans during storage at $7^{\circ} \mathrm{C}$ and shelf life at $20^{\circ} \mathrm{C}$.

\section{MATERIALS AND METHODS}

This experiment was carried out during the two successive seasons of 2018 and 2019 at Fruit Handling Department laboratories, Horticultural Research Institute, Agricultural Research Center, Giza. Common bean pods obtained from a private farm at Girza, Giza governorate $90 \mathrm{~km}$ south of Cairo. Common bean pods were harvested in the suitable maturity stage of marketing where, the pods are fleshly and the seeds are small and green (according to Abou El-Yazied, 2011) on $14^{\text {th }}$ and $13^{\text {th }}$ of October in the first and the second seasons, respectively. Then pods were transported to the laboratory. Pods uniform in length, diameter and color and free from blemishes were selected for storage experiment.

These pods were packed in perforated polyethylene and polypropylene bags or non-perforated polyethylene and polypropylene bags (non-PPEb film \& non-PPPb); $(30 \mu \mathrm{m}$ thickness, $15 \times 25 \mathrm{~cm}$ size) and each bag had $250 \mathrm{~g}$ as one replicate.

The bags were folded in two folds, the first rate or in three folds, the second rate then by using a perforated needle of 0.1 $\mathrm{mm}$ in diameter. Longitudinal holes were made at a distance of $1 \mathrm{~cm}$. to give 120 or 240 holes in each bag. The normal perforation rate was made by a punching machine with a rate of 4 holes only in length, with the bag folded only two folds, to give 32 holes in the existing bag. The bags were closed after packaging by a welding machine.

Pods from each treatment were packed in sealed polypropylene bags (30 $\mu \mathrm{m}$ thickness, $15 \times 25 \mathrm{~cm}$ size) and each bag had $250 \mathrm{~g}$ as one replicate. Sixteen replicates were prepared for each treatment. All treatments were stored at $7^{\circ} \mathrm{C}$ and $90-95 \%$ relative humidity for 7 , 14 and 21days.

\section{The following data were recorded during storage:}

\section{A. Pod Quality Physical Properties: -}

1- Weight loss percentage (WLP) was calculated using the following formula: (weight at time the beginning of storage -weight at each storage period) I (weight at time the beginning of storage) * 100

2- Unmarketable pod percentage (UPP) was calculated using the following formula: weight of unmarketable pods at each storage period, physiological or pathological) $I$ (weight at time the beginning of storage) *100

3- General appearance (GA) of Pods was determined visually using a scale from 1 to 5 ; where $5=$ excellent, $4=$ good, 3 $=$ acceptable $2=$ fair, $1=$ poor and $1=$ unusable. Samples rating at 2 and 1 were considered unmarketable.

4- Skin color and lightness of common bean pods were measured using a Minolta CR-400 Chroma Meter (Minolta Co. Itd. Osaka, Japan). The measurements of skin color and gloss were expressed in chromaticity values of hue angle $\left(h^{\circ}\right)$ and lightness (L), respectively. Two readings were taken at different locations of each pod during each data observation (McGuire, 1992).

5- Firmness of pods were measured in 15 pods (each five considered as one replicate) by Lfra texture analyzer instrument using a penetrating cylinder of $1 \mathrm{~mm}$ in diameter to a constant distance $3 \mathrm{~mm}$ inside the skin of fruits and by a constant speed $2 \mathrm{~mm}$ per sec, and the peak of resistance was recorded $\left(\mathrm{g} / \mathrm{cm}^{2}\right)$. 


\section{Experimental Design and Statistical Data Analysis}

The experimental design was completely randomized factorial design with three replicates. Three replicates from each treatment were taken at random and examined immediately after harvest and after 7,14 and 21 days at $7^{\circ} \mathrm{C}$ and $95 \% \mathrm{RH}$. Means significant difference (L.S.D. values at $P=0.05$ ) were determined using MSTAT-C statistical package (M-STAT, 1993) according to (Steel et al., 1997).

\section{RESULTS AND DISCUSSION}

1- Weight Loss and Unmarketable pods percentage of Common Beans during Cold Storage: -
Weight loss (WL) and Unmarketable pods percentage of common beans packed in perforated polyethylene and polypropylene bags or non-perforated polyethylene and polypropylene bags and stored at $7^{\circ} \mathrm{C}$ for 21 days shown in Tables (1 and 2). It is clear that weight loss and unmarketable pods percentage of common beans increased gradually and significantly with prolonging of storage period in the two seasons under this work. These findings are in agreement with those illustrated by Guo et al. (2008), Proulx et al. (2010), (Kinyuru et. al. (2011), Ubhi et al. (2014), El-Sayed et al. (2015), Shehata et al. (2015) and Soontornwat et al. (2015).

Table 1: Effect of Packaging Type and Perforation Rate on Weight Loss percentage of Common Beans during Cold Storage

\begin{tabular}{|c|c|c|c|c|c|}
\hline \multicolumn{6}{|c|}{ First Season } \\
\hline \multirow{2}{*}{ Treatments } & \multicolumn{5}{|c|}{ Storage Periods_Weeks } \\
\hline & 0 & 7 & 14 & 21 & Means \\
\hline NPPE & 0 & 0.60 & 0.69 & 1.12 & 0.60 \\
\hline NPPP & 0 & 0.58 & 1.40 & 1.67 & 0.91 \\
\hline PPE 1 $1^{\text {st }}$ rate & $\mathbf{0}$ & 0.79 & 1.65 & 2.40 & 1.21 \\
\hline PPP $1^{\text {st }}$ rate & 0 & 0.53 & 2.37 & 2.79 & 1.42 \\
\hline PPE $2^{\text {nd }}$ rate & 0 & 0.82 & 2.13 & 2.63 & 1.39 \\
\hline PPP $2^{\text {nd }}$ rate & 0 & 1.16 & 4.14 & 6.35 & 2.91 \\
\hline PPE Normal rate & 0 & 1.76 & 3.90 & 6.71 & 3.09 \\
\hline Means & 0.00 & 0.89 & 2.32 & 3.38 & \\
\hline \multicolumn{6}{|c|}{ Second Season } \\
\hline NPPE & 0 & 0.66 & 0.99 & 1.72 & 0.84 \\
\hline NPPP & 0 & 0.50 & 1.02 & 1.58 & 0.78 \\
\hline PPE $1^{\text {st }}$ rate & 0 & 0.99 & 1.54 & 2.13 & 1.16 \\
\hline PPP $1^{\text {st }}$ rate & 0 & 0.60 & 2.41 & 3.24 & 1.56 \\
\hline PPE $2^{\text {nd }}$ rate & 0 & 1.29 & 1.81 & 3.02 & 1.53 \\
\hline PPP $2^{\text {nd }}$ rate & 0 & 1.59 & 3.39 & 5.97 & 2.74 \\
\hline PPE Normal rate & 0 & 0.83 & 2.15 & 7.29 & 2.57 \\
\hline Means & 0.00 & 0.92 & 1.90 & 3.56 & \\
\hline \multirow{2}{*}{ Variable } & \multicolumn{5}{|c|}{ L.S.D. at $5 \%$} \\
\hline & Treat. & & Per. (S) & & $T * S$ \\
\hline First Season & 0.51 & & .392 & & 1.038 \\
\hline Second Season & 0.74 & & .559 & & 1.480 \\
\hline
\end{tabular}

NPPE: non -perforated polyethylene bags PPE: perforated polyethylene bags NPPP: non -perforated polypropylene bags PPP: perforated polyethylene bags 
M.E.M. Ahmed, et al,

Table 2: Effect of Packaging Type and Perforation Rate on Unmarketable pods percentage of Common Beans during Cold Storage

\begin{tabular}{|c|c|c|c|c|c|}
\hline \multicolumn{6}{|c|}{ First Season } \\
\hline \multirow{2}{*}{ Treatments } & \multicolumn{5}{|c|}{ Storage Periods_Weeks } \\
\hline & 0 & 7 & 14 & 21 & Means \\
\hline NPPE & $\mathbf{0}$ & 9.6 & 25.8 & 47.0 & 20.61 \\
\hline NPPP & 0 & 3.7 & 16.5 & 43.9 & 16.04 \\
\hline PPE 1 ${ }^{\text {st }}$ rate & $\mathbf{0}$ & 2.6 & 8.1 & 29.0 & 9.93 \\
\hline PPP $1^{\text {st }}$ rate & 0 & 4.2 & 12.7 & 21.1 & 9.51 \\
\hline PPE $2^{\text {nd }}$ rate & $\mathbf{0}$ & 3.4 & 10.5 & 32.9 & 11.70 \\
\hline PPP $2^{\text {nd }}$ rate & 0 & 3.3 & 12.4 & 31.8 & 11.88 \\
\hline PPE Normal rate & 0 & 3.3 & 8.0 & 30.2 & 10.38 \\
\hline Means & 0.00 & 4.30 & 13.44 & 33.71 & \\
\hline \multicolumn{6}{|c|}{ Second Season } \\
\hline NPPE & $\mathbf{0}$ & 10.1 & 23.1 & 50.9 & 21.03 \\
\hline NPPP & 0 & 7.7 & 12.7 & 37.9 & 14.58 \\
\hline PPE $1^{\text {st }}$ rate & 0 & 4.2 & 9.5 & 26.9 & 10.15 \\
\hline PPP $1^{\text {st }}$ rate & 0 & 3.8 & 11.2 & 25.8 & 10.17 \\
\hline PPE $2^{\text {nd }}$ rate & $\mathbf{0}$ & 3.1 & 7.9 & 26.7 & 9.45 \\
\hline PPP $2^{\text {nd }}$ rate & 0 & 3.4 & 13.1 & 30.3 & 11.69 \\
\hline PPE Normal rate & 0 & 4.1 & 12.5 & 31.1 & 11.95 \\
\hline Means & 0.00 & 5.21 & 12.86 & 32.80 & \\
\hline \multirow{2}{*}{ Variable } & \multicolumn{5}{|c|}{ L.S.D. at 5\% } \\
\hline & Treat & & Per. (S) & & $T * S$ \\
\hline First Season & 3.2 & & 2.46 & & 6.5 \\
\hline Second Season & 2.8 & & 2.19 & & 5.79 \\
\hline
\end{tabular}

NPPE: non -perforated polyethylene bags

NPPP: non -perforated polypropylene bags

Shehata et al. (2018) demonstrated that weight loss percentage of green beans increased gradually during storage. Also, these results in line with those mentioned by Gomaa et al. (2009) and Anurag et al. (2015) on green peas, Nasef et al. (2018) on snow peas, Gad ELRab (2013) and Shehata et al. (2019) on Sweet pepper. Moreover, these results are supported by the findings of Sandhya and Singh (2004), Gomaa et al. (2009) and El-tahan, et al., (2016) who found that snap bean pods decayed percentage increased gradually with increasing of storage period.

Concerning the effect of packing perforation rate, it is obvious from the data shown in Table (1) that weight loss percentage of common beans increased
PPE: perforated polyethylene bags

PPP: perforated polyethylene bags

gradually and significantly with increasing the packing perforation rate. Data cleared that common beans packed in non-perforated polyethylene and nonperforated polypropylene bags showed the lowest percentage of weight loss during the two seasons in this work. On contrast, common beans packed in normal-perforated polyethylene bags showed the highest percentage of weight loss followed by those packed in the highest perforation rate during the two seasons in this work. These results are in line with those mentioned by Ubhi et al. (2014) and Shehata et al. (2018) who reported that pods stored in none perforated bags had the lowest percentage weight loss during storage, while those stored in bags had the highest perforation rate had the highest 
percentage of weight loss during the storage periods.

2- General Appearance and firmness of Common Beans pods during Cold Storage: -

General appearance and firmness of common beans pods packed in perforated polyethylene and polypropylene bags or non-perforated polyethylene and polypropylene bags and stored at $7^{\circ} \mathrm{C}$ for 21 days shown in Tables (3 and 4). It is clear that, general appearance and firmness of common beans decreased gradually and significantly with prolonging of storage period in the two seasons under this work. These finding are in agreement with those illustrated by Shehata et al. (2015) and Shehata et al. (2018). They mentioned that general appearance of green beans pods gradually and significantly decreased with prolonging of storage period and shelf life. In addition, these results are in agreement with the finding of Nasef et al. (2018) on snow peas, Shehata et al. (2019) and Gad EL-Rab (2013) on sweet pepper as they reported that firmness significantly decreased with the increasing of storage period. Moreover, these finding are also in agreement with those illustrated by Proulx, et al., 2010, who mentioned that green beans firmness gradually and significantly decreased with increasing of storage period.

Table 3: Effect of Packaging Type and Perforation Rate on General Appearance of Common Beans during Cold Storage

\begin{tabular}{|c|c|c|c|c|c|}
\hline \multicolumn{6}{|c|}{ First Season } \\
\hline \multirow{2}{*}{ Treatments } & \multicolumn{5}{|c|}{ Storage Periods_Weeks } \\
\hline & 0 & 7 & 14 & 21 & Means \\
\hline NPPE & 5.0 & 4.0 & 3.0 & 1.7 & 3.42 \\
\hline NPPP & 5.0 & 4.0 & 3.3 & 2.0 & 3.58 \\
\hline PPE $1^{\text {st }}$ rate & 5.0 & 5.0 & 3.3 & 3.7 & 4.25 \\
\hline PPP $1^{\text {st }}$ rate & 5.0 & 5.0 & 4.0 & 3.7 & 4.41 \\
\hline PPE $2^{\text {nd }}$ rate & 5.0 & 5.0 & 4.0 & 4.0 & 4.50 \\
\hline PPP $2^{\text {nd }}$ rate & 5.0 & 4.7 & 3.7 & 3.7 & 4.25 \\
\hline PPE Normal rate & 5.0 & 4.3 & 3.7 & 3.7 & 4.17 \\
\hline Means & 5.00 & 4.57 & 3.57 & 3.18 & \\
\hline \multicolumn{6}{|c|}{ Second Season } \\
\hline NPPE & 5.0 & 3.7 & 2.3 & 2.0 & 3.25 \\
\hline NPPP & 5.0 & 3.3 & 2.3 & 1.7 & 3.08 \\
\hline PPE $1^{\text {st }}$ rate & 5.0 & 4.3 & 4.0 & 3.0 & 4.08 \\
\hline PPP $1^{\text {st }}$ rate & 5.0 & 3.7 & 3.3 & 2.7 & 3.67 \\
\hline PPE $2^{\text {nd }}$ rate & 5.0 & 5.0 & 3.0 & 3.0 & 4.00 \\
\hline PPP 2 ${ }^{\text {nd }}$ rate & 5.0 & 4.7 & 3.7 & 3.0 & 4.08 \\
\hline PPE Normal rate & 5.0 & 4.0 & 3.0 & 3.3 & 3.83 \\
\hline Means & 5.00 & 4.10 & 3.10 & 2.67 & \\
\hline \multirow{2}{*}{ Variable } & \multicolumn{5}{|c|}{ L.S.D. at $5 \%$} \\
\hline & Treat & & Per. (S) & & $\mathbf{T} * \mathbf{S}$ \\
\hline First Season & 0.2 & & .226 & & 0.598 \\
\hline Second Season & 0.3 & & .234 & & 0.619 \\
\hline
\end{tabular}

NPPE: non -perforated polyethylene bags NPPP: non -perforated polypropylene bags
PPE: perforated polyethylene bags PPP: perforated polyethylene bags 
M.E.M. Ahmed, et al,

Table 4: Effect of Packaging Type and Perforation Rate on Firmness of Common Beans during Cold Storage, $\left(\mathrm{gm} / \mathrm{m}^{2}\right)$

\begin{tabular}{|c|c|c|c|c|c|}
\hline \multicolumn{6}{|c|}{ First Season } \\
\hline \multirow{2}{*}{ Treatments } & \multicolumn{5}{|c|}{ Storage Periods_Weeks } \\
\hline & 0 & 7 & 14 & 21 & Means \\
\hline NPPE & 19.6 & 16.7 & 14.4 & 11.8 & 15.63 \\
\hline NPPP & 19.6 & 16.5 & 14.8 & 12.3 & 15.79 \\
\hline PPE $1^{\text {st }}$ rate & 19.6 & 19.7 & 16.0 & 13.9 & 17.30 \\
\hline PPP $1^{\text {st }}$ rate & 19.6 & 17.9 & 16.8 & 15.2 & 17.36 \\
\hline PPE $2^{\text {nd }}$ rate & 19.6 & 19.0 & 17.5 & 15.0 & 17.77 \\
\hline PPP 2 ${ }^{\text {nd }}$ rate & 19.6 & 15.9 & 15.7 & 13.5 & 16.19 \\
\hline PPE Normal rate & 19.6 & 18.1 & 15.1 & 14.0 & 16.70 \\
\hline Means & 19.63 & 17.67 & 15.76 & 13.65 & \\
\hline \multicolumn{6}{|c|}{ Second Season } \\
\hline NPPE & 18.0 & 15.0 & 12.6 & 11.5 & 14.26 \\
\hline NPPP & 18.0 & 15.0 & 12.4 & 11.5 & 14.24 \\
\hline PPE $1^{\text {st }}$ rate & 18.0 & 17.3 & 13.4 & 12.9 & 15.38 \\
\hline PPP $1^{\text {st }}$ rate & 18.0 & 16.1 & 14.8 & 13.7 & 15.64 \\
\hline PPE $2^{\text {nd }}$ rate & 18.0 & 17.0 & 15.4 & 13.5 & 15.97 \\
\hline PPP $2^{\text {nd }}$ rate & 18.0 & 14.4 & 15.3 & 14.3 & 15.52 \\
\hline PPE Normal rate & 18.0 & 15.2 & 13.9 & 13.6 & 15.18 \\
\hline Means & 17.98 & 15.72 & 13.97 & 13.00 & \\
\hline \multirow{2}{*}{ Variable } & \multicolumn{5}{|c|}{ L.S.D. at $\mathbf{5 \%}$} \\
\hline & Treat & & Per. (S) & & $T * S$ \\
\hline First Season & 1.23 & & 0.931 & & 2.464 \\
\hline Second Season & $0.9 \mathrm{~s}$ & & 0.751 & & 1.987 \\
\hline
\end{tabular}

NPPE: non -perforated polyethylene bags NPPP: non -perforated polypropylene bags

Concerning the effect of packing perforation rate, it is obvious from the data shown in Table (3) that green bean pods packed in the second rate (perforated PPE and PPP $2^{\text {nd }}$ rate bags) showed the highest general appearance score followed by those of packed in the normal perforation rate during the two seasons in this work with no significant differences in some cases. On contrast, green bean pods packed in nonperforated polyethylene and nonperforated polypropylene bags showed the lowest general appearance score during the two seasons in this work.

These results are in accordance with those demonstrated by Nasef et al. (2018) who demonstrated that, snow peas
PPE: perforated polyethylene bags PPP: perforated polyethylene bags

packaged in micro-perforated films, especially with 12 micro-holes, showed the highest visual appearance. On contrast, the lowest score values were observed with non-perforated then smart packages overall cold storage plus retail sale periods. On contrast, these results disagree with those illustrated by Shehata et al. (2015) and Shehata et al. (2018) who reported that green beans pods packed in non-perforated polypropylene bags showed the highest intensities of freshness, greenness, and snappiness in comparison with those packed in perforated polypropylene bags either micro or normal perforated during cold storage. 
On the other hand, it is clear from the results of Table (4) that common bean pods packed in the second rateperforated PPE and PPP $2^{\text {nd }}$ rate bags showed the highest firmness followed by those packed in the normal perforation rate during the two seasons in this work with no significant differences in most cases. On contrast, common beans packed in non-perforated polyethylene and non-perforated polypropylene bags showed the lowest firmness during the two seasons in this work. These results are in line with those illustrated by Ubhi et al. (2014) who mentioned that snap beans packed in LDPE $37.5 \mu \mathrm{m}$ film packages, package having 4 perforations recorded the highest firmness followed by package having two perforations and least firmness was recorded in nonperforated packages.

\section{3- Color and lightness of Common Bean pods during Cold Storage: -}

It is clear that, color, represented as hue angle and lightness of common beans packed in perforated polyethylene and polypropylene bags or nonperforated polyethylene and polypropylene bags and stored at $7^{\circ} \mathrm{C}$ for 21 are days shown in Tables (5 and 6). Color and lightness of common beans decreased gradually and significantly with prolonging of storage period in the two seasons under this work.

Table 5: Effect of Packaging Type and Perforation Rate on Lightness of Common Beans during Cold Storage

\begin{tabular}{|c|c|c|c|c|c|}
\hline \multicolumn{6}{|c|}{ First Season } \\
\hline \multirow{2}{*}{ Treatments } & \multicolumn{5}{|c|}{ Storage Periods_Weeks } \\
\hline & 0 & 7 & 14 & 21 & Means \\
\hline NPPE & 58.8 & 58.1 & 57.3 & 59.3 & 58.34 \\
\hline NPPP & 58.8 & 58.9 & 56.6 & 54.5 & 57.18 \\
\hline PPE $1^{\text {st }}$ rate & 58.8 & 57.6 & 56.6 & 57.1 & 57.53 \\
\hline PPP $1^{\text {st }}$ rate & 58.8 & 59.4 & 56.9 & 55.6 & 57.64 \\
\hline PPE $2^{\text {nd }}$ rate & 58.8 & 60.4 & 59.0 & 56.4 & 58.64 \\
\hline PPP $2^{\text {nd }}$ rate & 58.8 & 64.2 & 56.1 & 55.8 & 58.70 \\
\hline PPE Normal rate & 58.8 & 59.8 & 54.9 & 57.5 & 57.75 \\
\hline Means & 58.75 & 59.76 & 56.76 & 56.60 & \\
\hline \multicolumn{6}{|c|}{ Second Season } \\
\hline NPPE & 61.1 & 59.2 & 58.4 & 56.9 & 58.88 \\
\hline NPPP & 61.1 & 58.4 & 56.6 & 56.4 & 58.13 \\
\hline PPE $1^{\text {st }}$ rate & 61.1 & 57.1 & 57.9 & 56.0 & 58.02 \\
\hline PPP 1 $1^{\text {st }}$ rate & 61.1 & 61.1 & 56.6 & 56.6 & 58.83 \\
\hline PPE $2^{\text {nd }}$ rate & 61.1 & 56.8 & 56.5 & 57.1 & 57.85 \\
\hline PPP 2 ${ }^{\text {nd }}$ rate & 61.1 & 60.1 & 59.0 & 55.6 & 58.94 \\
\hline PPE Normal rate & 61.1 & 58.9 & 58.2 & 55.7 & 58.48 \\
\hline Means & 61.10 & 58.79 & 57.59 & 56.30 & \\
\hline \multirow{2}{*}{ Variable } & \multicolumn{5}{|c|}{ L.S.D. Values at $5 \%$} \\
\hline & Treat. & & Per. (S) & & $T * S$ \\
\hline First Season & 1.8 & & 1.40 & & 3.70 \\
\hline Second Season & 1.0 & & 0.78 & & 2.05 \\
\hline
\end{tabular}

NPPE: non -perforated polyethylene bags PPE: perforated polyethylene bags NPPP: non -perforated polypropylene bags PPP: perforated polyethylene bags 
M.E.M. Ahmed, et al,

Table 6: Effect of Packaging Type and Perforation Rate on Colour of Common Beans during Cold Storage

\begin{tabular}{|c|c|c|c|c|c|}
\hline \multicolumn{6}{|c|}{ First Season } \\
\hline \multirow{2}{*}{ Treatments } & \multicolumn{5}{|c|}{ Storage Periods_Weeks } \\
\hline & $\mathbf{0}$ & \multirow{2}{*}{$\begin{array}{c}7 \\
116.2\end{array}$} & 14 & 21 & Means \\
\hline NPPE & 116.5 & & 110.1 & 105.7 & 112.13 \\
\hline NPPP & 116.5 & $\begin{array}{l}116.2 \\
1178\end{array}$ & 110.9 & 109.4 & 113.66 \\
\hline PPE 1 ${ }^{\text {st }}$ rate & 116.5 & $\begin{array}{l}117.8 \\
116.7\end{array}$ & 110.6 & 113.1 & 114.23 \\
\hline PPP $1^{\text {st }}$ rate & 116.5 & 111.2 & 107.7 & 115.5 & 112.72 \\
\hline PPE $2^{\text {nd }}$ rate & 116.5 & 114.0 & 112.0 & 111.3 & 113.43 \\
\hline PPP $2^{\text {nd }}$ rate & 116.5 & 117.0 & 112.7 & 111.0 & 114.30 \\
\hline PPE Normal rate & 116.5 & 113.0 & 116.6 & \multirow{2}{*}{$\begin{array}{c}110.2 \\
110.89\end{array}$} & 114.07 \\
\hline Means & 116.50 & 115.13 & 111.51 & & \\
\hline \multicolumn{6}{|c|}{ Second Season } \\
\hline NPPE & 117.5 & 116.0 & 109.5 & 104.0 & 111.8 \\
\hline NPPP & 117.5 & 115.5 & 110.5 & 107.5 & 112.8 \\
\hline PPE $1^{\text {st }}$ rate & 117.5 & 117.5 & 110.0 & 110.5 & 113.9 \\
\hline PPP $1^{\text {st }}$ rate & 117.5 & 112.0 & 110.0 & 111.5 & 112.8 \\
\hline PPE $2^{\text {nd }}$ rate & 117.5 & 113.5 & 111.0 & 107.5 & 112.4 \\
\hline PPP $2^{\text {nd }}$ rate & 117.5 & 114.0 & 113.5 & 108.0 & 113.3 \\
\hline PPE Normal rate & 117.5 & 114.0 & 114.0 & 108.0 & 113.4 \\
\hline Means & 117.5 & 114.6 & 111.2 & 108.1 & \\
\hline Variabla & & & L.S.D. at 5 & & \\
\hline Vantalote & Treat. & & S. Per. (S) & & $T * S$ \\
\hline First Season & $1.4 \mathrm{C}$ & & 1.06 & & 2.80 \\
\hline Second Season & 1.6 & & 1.24 & & 3.29 \\
\hline
\end{tabular}

NPPE: non -perforated polyethylene bags

NPPP: non -perforated polypropylene bags

These findings are in agreement with those illustrated by Proulx, et al. (2010), Ubhi et al. (2014), Anurag et al. (2015) in their studies on green peas, Gad EL-Rab (2013) and Shehata et al. (2019) in their study on Sweet Pepper. They demonstrated that, color of green beans pods, represented as either hue angle or $P$ value, gradually decreased with prolonging of storage period. Moreover, these findings are supported by the illustration of Gad EL-Rab (2013) and Shehata, et al. (2019) who found that sweet pepper snap bean pods lightness decreased gradually and significantly during storage.

Moreover, the findings partially agree with the findings of lightness of green bean pods had no clear trend during storage. Proulx, et al. (2010). On contrary these results disagree with those cleared
PPE: perforated polyethylene bags

PPP: perforated polyethylene bags

by Anurag et al. (2015) on green peas. They illustrated that, lightness of pods gradually and significantly increased with prolonging of storage.

On the other side, data presented in Table (5) clearly indicated that, there were no significant differences in lightness of common beans packed in non-perforated, perforated or normalperforated bags during the two seasons under this work.

Concerning the effect of packing perforation rate, it is obvious from the data shown in Table (5) that, color, represented as hue angle, of common beans deterioration rate decreased gradually with the increasing packing perforation rate. Data cleared also that, common bean pods packed in normalperforated polyethylene bags showed the highest values of color, represented as 
hue angle followed by those packed in the highest perforation rate during the two seasons in this work. This means that pods had the best color, greenest color, compared with the other treatments. On contrast, common beans packed in non-perforated polyethylene and non-perforated polypropylene bags showed the lowest values of color, represented as hue angle during the two seasons in this work. However, these results were insignificant in most cases. These results are in line with those mentioned by Ubhi et al. (2014) who illustrated that, snap beans packed in LDPE $37.5 \mu \mathrm{m}$ film packages, package having 4 perforations recorded the highest greenness followed by package having 2 perforations and the least greenness was recorded in nonperforated packages. On the other hand, these results disagree with those findings by Shehata et al. (2015) and Shehata et al. (2018) who demonstrated that, green bean pods packed in nonperforated polypropylene bags showed the highest greenness compared with the other treatments during storage.

\section{Conclusion}

Overall results, we can conclude that reducing bag perforation rate well led to improve common beans storability and reduce deterioration rate of its quality parameter including weight loss, decay incidence, freshness, general appearance and color during storage.

\section{REFERENCES}

Abd El-Mageed, M. A. (2015). Studies on Improving Postharvest Quality of Common Beans for Marine Dispatch. M. Sc. Thesis, Fac. Agric., Ain Shams Univ., Cairo, Egypt.

Abou El-Yazied, A. (2011). Growth, biochemical constituents and yield of snap bean as influenced by low gamma irradiation doses under different sowing dates. Australian Journal of Basic and Applied Sciences, 5(10): 518-530.

Anurag R. K., M. Manjunatha, S. N. Jha and L. Kumari (2015). Storage quality of shelled green peas under modified atmosphere packaging at different storage conditions, J Food Sci Technol, 53(3): 1640-1648.

El-Sayed, H.A., M.M. Zaghloul, K.A.M. Nour and R.H. Attia (2015). Treatment of snap bean plants grown under sandy soil conditions with some natural materials and its relation to growth, yield and pod quality. J. plant production, Mansoura Univ., 6(3): 395421.

El-tahan, I. M., M. A. El-hamahmy, A. E. Elewa and A. I. Baz (2016). Biochemical and anatomical characters of snap bean (Phaseolus vulgaris L.) Pods under furrow and drip irrigation system at harvest and during postharvest. $J$. of Plant Production Sciences; Suez Canal University, 5 (1): 13-22.

Emond, J.P., F. Castaigne, C.J. Toupin and D. Desilets (1991). Mathematical modeling of gas exchange in modified atmosphere packaging. Trans ASAE 34(1):239-245.

Fishman, S., V. Rodov and S. BenYahoshua (1996). Mathematical model for perforation effect on oxygen and water vapour dynamics in modi- fied atmosphere packages. J. Food Sci., 61(5): 956-961.

Gad EL-Rab, N.A. (2013). Effect of some pre and postharvest treatments on yield, quality and storability of sweet pepper. M.Sc. Thesis, Fac. Agric., Cairo Univ., Cairo, Egypt, 138 p.

Gomaa, R. B., Ghada M. Medany and F. R. $H$. Hassan (2009). Effect of packaging materials and modified atmosphere packaging on shelf-life of green peas. 
J. Agric. Sci. Mansoura Univ., 34 (5): 4577 - 4592.

Guo, L., Y. Maa, D. Sun and P. Wang (2008). Effects of controlled freezingpoint storage at $0^{\circ} \mathrm{C}$ on quality of green bean as compared with cold and room temperature storages. J. of Food Engineering, 86, 25-29.

Kerlous, A.N.K. (1997). Effect of sowing dates and water stress on productivity of bean (Phaseolus vulgaris L.) plants. M. Sc. Thesis, Fac. Agric., Ain Shams Univ., Cairo, Egypt.

Kinyuru, J.N., K. Kahenya, P.M. Muchui and $H$. Mungai (2011). Influence of post-harvest handling on the quality of snap bean (Phaseolus vulgaris L.). J Agri Food Technol 1(5): 43-46.

McGuire, R.G. (1992). Reporting of objective color measurements. HortSci., 27 (12): 1254-1255.

M-STAT (1993). A microcomputer program for the design, arrangement and analysis of agronomic research experiments. Michigan State University.

Nasef, I.N., S. K. El-Seifi, M. A. Hassana, Rawia E. I. El-Bassiouny and M. W. and $M$. Elwan (2018). Effect of modified atmosphere packaging on storability, shelf life and quality of snow peas. Hortscience Journal of Suez Canal University, 81-90.

Proulx, E., Y. Yagiz, M. C. N. Nunes and J. P. Emond (2010). Quality attributes limiting Ssnap bean (Phaseolus vulgaris L.) postharvest life at chilling and Non-chilling temperatures. Hortscience, 45(8): 1238-1249.

Rai, D.R., SN Jha, O.D Wanjari and R.T Patil (2009). Chromatic changes in broccoli (Brassica oleracea italic) under modified atmospheres in perforated film packages. Food Sci. Technol. Int., 15(4):387-395.

Sandhya and A.K. Singh (2004). Packaging of shelled peas in highdensity polyethylene. J. Res. Punjab
Agric. Univ., 41(1): 110-118

Scetar, M., M. Kurek and K. Galic (2010). Trends in fruit and vegetable packaging-a review. Croatian J. Food Technol Biotechnol. Nutri., 5(3-4): 6986

Shehata, S. A., M. EL- M. Saad, M.A. Saleh and S. A. Atala (2019). Effect of some Biostimulants Materials on Growth, Yield, Quality and Storability of Sweet Pepper. Annals of Agric. Sci., Moshtohor, Vol. 57(1):77-88. http:/laasj.bu.edu.eg/index.php

Shehata, S.A., Z.A. Said, M.M Attia and M.A. Rageh (2015). Effect of foliar application of micronutrients, magnesium and wrapping films on yield, quality and storability of green bean pods. Fayoum J. Agric. Res. \& Dev., 30(1):121-139.

Shehata, S.A., S.Z. Abd El-Rahman, M.S. Emam, M.A. El-Helaly and Gad N.A. ElRab (2018). Effect of Some BioStimulants and Packaging Material on Quality Attributes of Snap Beans during Storage and Shelf Life Conditions. Annals of Agric. Sci., Moshtohor, Vol. 56(2): 371 - 384.

Soontornwat, A., N. Pongpresert and V. Srilaong (2015). Quality of organic and conventional Yardlong bean stored at low temperature. Acta Horticulturae, no.1088: 255-259.

Steel, R.G.D., J.H. Torrie and D.A. Diskey (1997). "Principles and Procedures of Statistics. A Biometrical Approach", $3^{\text {rd }}$ ed., McGrow-Hill Publishing Company, New York, USA, pp. 336376.

Ubhi, G. S., S. R. Sharma, J. S. Grewal and M. Javed (2014). Effect of modified atmosphere packaging on French beans (Phaseolus vulgaris L.) during Cold Storage. International J. of Engineering Sci. Invention, V. 3(5): 38-45. 
تأثير نوع العبوة ومعدل التثقيب على القدرة التخزينية وجودة قرون الفاصوليا: أ- الخصائص الفيزيائية

محمد السيد محمد أحمد(")، محمود على احمد محمد)"، ابراهيم الصاوى البلاط (')، خالد عطا ابراهيم نمير(')

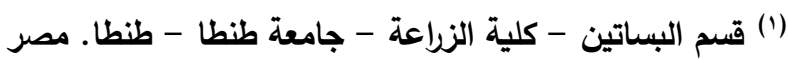

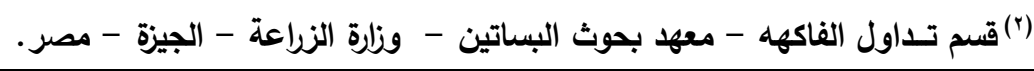

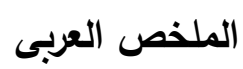

تعتبر الفاصوليا (Phaseolus vulgaris L.) واحدة من أهم المحاصيل البقولية المنزرعة في مصر سواء للاستهلاك المحلي أو للتصدير. تعتبر عبوات البولى ايثلين منخفض الكثافة واحدة من اكثر الطرق المتبعة لزيادة القدرة

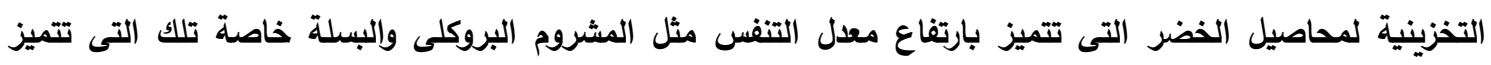

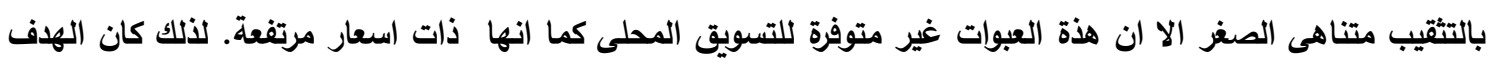

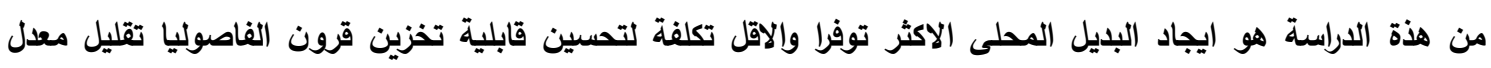

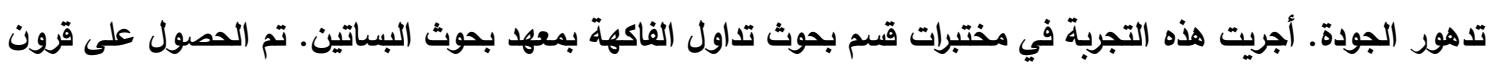

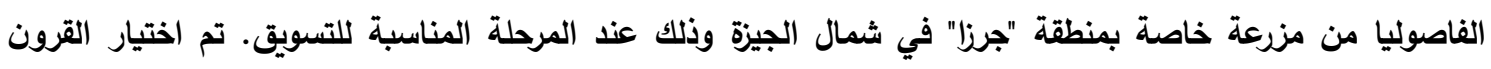

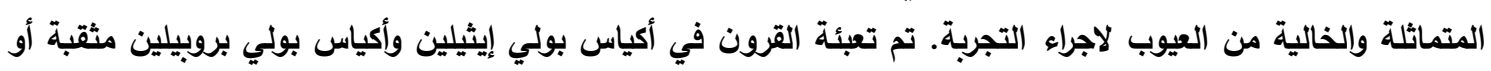

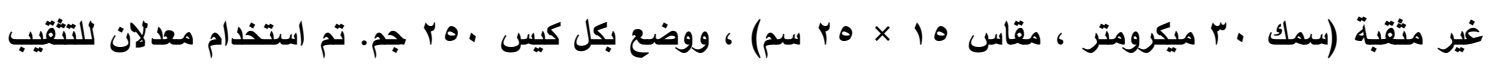

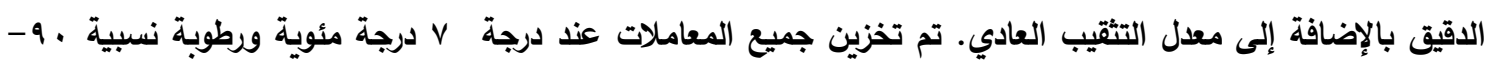

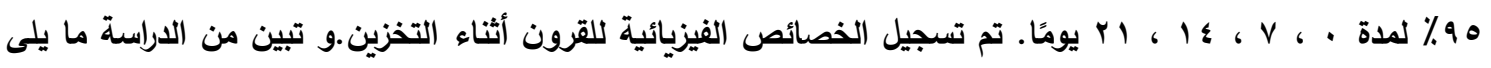

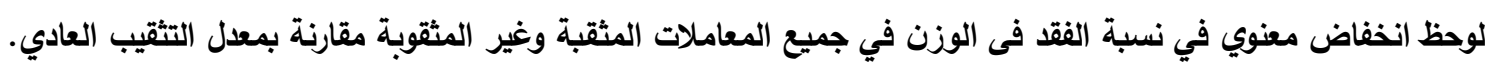

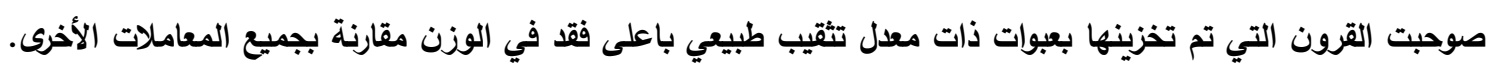

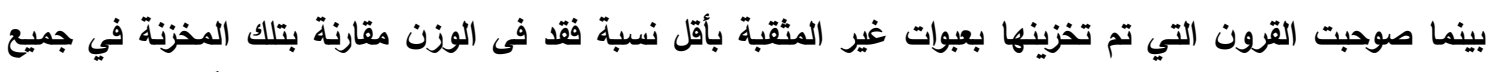

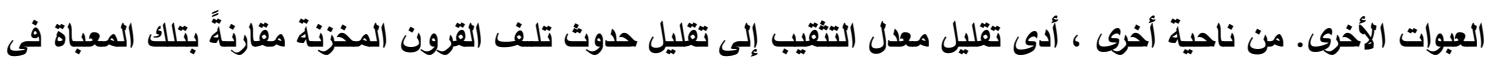

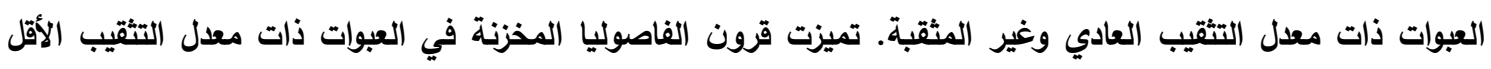

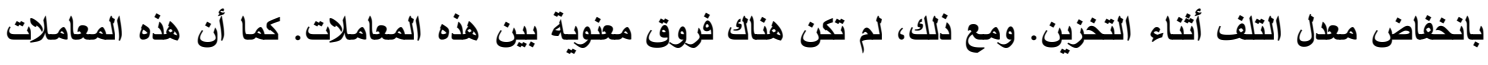

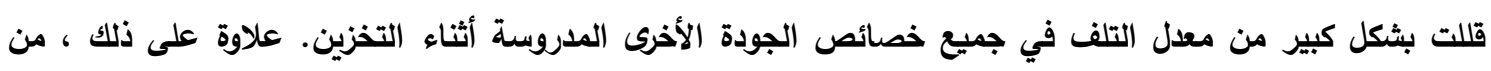

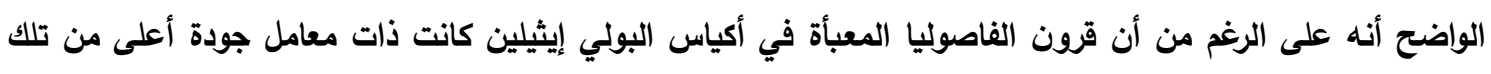

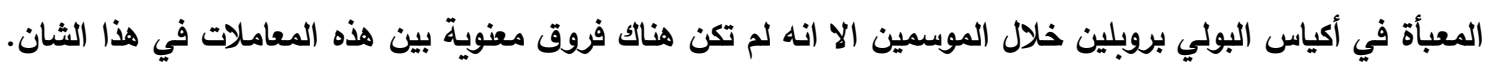

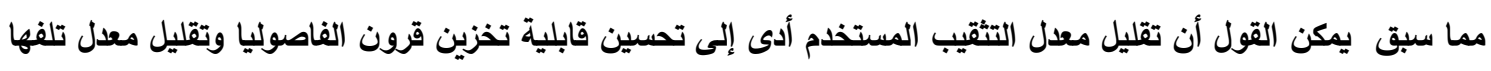
أثناء التخزين.

السادة المحكمين كلية الزراعة - جامعة دمياط أ.د/ محمود أحمد عبدالهادى كلية الزراعة - جامعة المنوفية

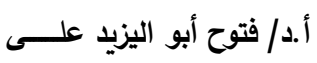

